\title{
Impact of Foreign Direct Investment, Foreign Portfolio Investment and Diaspora Remittances on Kenya's Economic Growth
}

\author{
Joan Serem ${ }^{1}$, Tobias Olweny ${ }^{2}$ \\ ${ }^{1}$ Post Graduate Student, School of Business, Jomo Kenyatta University of Agriculture and Technology, Kenya \\ ${ }^{2}$ Lecturer School of Business, Jomo Kenyatta University of Agriculture and Technology, Kenya
}

\begin{abstract}
The Objective of this study is to find out the effect of capital flows on economic growth in Kenya, With Three specific objectives; To investigate the effect of foreign direct investment on economic growth in Kenya, to find out the effect of foreign portfolio investment on economic growth in Kenya, and to determine the effect of diaspora remittances on economic growth in Kenya. Quarterly data from 2002 to 2017 was used in the study, and Descriptive research design and inferential research design were used to analysis the data. Descriptively, mean and standard deviation were used and inferentially the Auto regressive distribution Lag technique using the STATA software Version 15. Diagnostic tests were conducted on the data; Normality test using Jarque Bera test supported by the skewness and Kurtosis results; Unit root was tested using the Augmented Dickey Fuller Test .The Auto Regressive Distributed Lag regression short run results show that, foreign direct investment had an positive and insignificant effect on gross domestic product, whereas foreign portfolio investment had a positive and statistically significant short run effect on gross domestic product at $1 \%$ level of significance and diaspora remittances had a positive and very significant effect of gross domestic product at 5\% level of significance. The Error Correction Model regression results showed that in the long run, Foreign Direct Investment, Foreign Portfolio Investment, and Diaspora Remittances had a positive and very significant effect on the economic growth at $1 \%$ level of significance.
\end{abstract}

KEYWORDS: Capital flows, Economic growth, Foreign direct investment, foreign portfolio investment, Diaspora remittances

\section{INTRODUCTION}

The global financial crisis of 2008-2009 rekindled the debate about the desirability of financial integration in both advanced economies and emerging markets. Emerging markets' robust recovery from the crisis and their stronger long-term growth prospects are the fundamental drivers of capital flows. Episodes of financial and economic distress related to capital flows - e.g., Asian financial crisis of 19971998 - and relative under-development of their financial systems further heighten such concerns (Aizenman, 2011). The crisis enhances the momentum for empirically revisiting the relationship between capital flows and economic growth. An important issue in the debate over the desirability of freer capital mobility for developing countries is whether capital flows have significant effect on economic growth. This calls for an enhanced capital flow to overcome the high poverty levels and improve the standard of living in developing countries. This is argument is supported by Proponents of capital account liberalization who explains that growthpromoting attributes of capital inflows are key benefits of financial integration for developing countries (Blair, 2003; Obstfeld, 2009).

In light of the heterogeneous nature of capital flows, it may not be sensible to lump them together in investigating the impact of capital flows on economic growth (Aizenman, Jinjarak \& Park, 2011). Foreign direct investment, diaspora remittances and portfolio equity investment are fundamentally different from each other since the foreign direct investment is associated with ownership and control while the latter is not

Kenya is working hard to achieve the goals as set in the vision 2030. Internal sources of finance are not usually enough to finance both recurrent and development expenditures of the country (Afrodad, 2003). To curb this financial constraint, the country obtains external finances in terms of foreign direct investment, foreign portfolio investment, foreign debt, foreign aid and remittances.

\section{Statement of the problem}

There is a great interest in finding out the effect of capital flows on economic growth both in the developing and developed nations. According to Edwards (2004) Capital has a role for every economy regardless of its level. For developed countries it is used to support development that is sustainable whereas for developing countries it is used to increase capital accumulation and investment rate to create conditions that spur economic growth. This therefore means that the wide scope of studies that have been done on 
developed nations cannot be used as a reference point to formulate polices for developing countries as it will be based on foreign ideas hence may not be applicable for a developing country like Kenya. Empirical studies that have been done on the impact of capital flows on economic growth are also cross country and few studies have been done on specific countries thus failing to bring out unique characteristics of these countries.

Most of the available studies on the relationship between capital flows and economic growth have focused mainly on other countries and regions over the previous periods, hence demanding a more current and up-to-date study of these subjects in Kenya. Also, there is limited and updated literature on studies on the effect of the recent capital flows on the economic growth in Kenya capturing the recent increase in capital flows and this study sought to fill this gap. This necessitated the need to carry this study to establish the effects of capital flows on economic growth in Kenya.

\section{OBJECTIVES OF THE STUDY General Objective}

i. To assess the effect of capital flows on economic growth in Kenya.

\section{Specific objectives}

The study was guided by the following specific objectives;

i. To investigate the effect of foreign direct Investment on economic growth in Kenya.

ii. To find out the effect of foreign portfolio investment on economic growth in Kenya.

iii. To determine the effect of diaspora remittances on economic growth in Kenya.

\section{THEORETICAL FRAMEWORK}

The study is based on the following theories

\section{i. Neoclassical Theory}

It was developed by Robert Solow and Trevor Swan in 1976. The theory advocates that the rate of gross domestic product growth increases when an economy allocates a higher share of gross domestic product to investment, decreases when physical capital stock depreciates at a higher rate, and increases when there is fast growth in technology and total factor productivity. In summary the theory illustrates that economic growth is a function of productivity, accumulation of capital and technological progress (Stonier and Hague, 1975). In summary, this theory states that economic growth is as a result of manufacturing, capital accumulation and technological innovation. It supports the rise in gross domestic product where a large share of gross domestic product is allocated to investment and declines as physical capital supplies (Factors of production) depreciates.

\section{ii. Industrial Organization Theory}

This theory was developed by Hymer in 1976. According the Hymer, firm specific advantages are mainly the technological advantages that help in the production of new products, the possession of marketing knowledge which helps in the development of special marketing skills, superior organizational and management setup and improved processing. Since the market is imperfect, rival firms do not avail of the technological advantage. International firm harvests huge profits. Caves (1971) feels that firm-specific advantages are transmitted more effectively if the firm participates effectively in the production in the host country than through other ways such as export or licensing agreements. It is based on the imperfect nature of the market an investing firm operates. Central concern is to provide an explanation of firm's investment abroad. It also articulates the fact that policies by the government play a key role in encouraging investment by international firms.

iii. The two Gap Model

The Two-Gap Model of economic growth was initiated by Chenery in 1962. This theory shows that growth requires investments, which in turn require savings. Investment funds can either be foreign or domestic savings. The first gap arises when the country's saving are inadequate to support capital accumulation needed to achieve a given growth target. The other gap identified by the theory is the inadequacy of foreign exchange earning which to acquire the import of capital goods required. The savings and foreign exchange gap problems are faced in most emerging nations. the model assumes that increase in investment will increase the growth rate hence leading to a further increase in capital imports. Notwithstanding, the Two-Gap Model fails to identify the allocation of foreign exchange earnings and reserve funds as key however centres around on its availability (Evans and Hnatkovska, 2007)

\section{EMPIRICAL LITERATTURE}

\section{Foreign direct investment and economic growth}

Levine and Carkovic (2002) conducted a study on the impact of foreign direct investment on economic growth and pooled data from 72 countries between 1960 and 1995. The findings of the study showed that foreign direct investment flows do not exert and positive impact on the economic growth of a country. A study by Chowdhury and Marrotas (2005) examined the causal relationship between foreign direct investment and economic growth for three developing countries, namely: Chile, Malaysia and Thailand. The conclusion was that gross domestic product causes foreign direct investment in the case of Chile and not vice versa, and that there was bidirectional causality for Malaysia and Thailand. Adeniyi et al. (2012) did a study on the link between foreign direct investment and economic growth for Cote d'Ivoire, Gambia, Ghana and Nigeria for the period 1970-2005.The findings indicated that there was no causal relationship from either foreign direct investment or financial development to economic growth and that there were statistically insignificant coefficients on both lagged foreign 
direct investment and financial development in Nigeria. Further findings showed that there was lack of both short- and long-run influence of foreign direct investment on economic growth in Sierra Leone, that economic growth and foreign direct investment are better linked by sound intermediating financial institutions, and that the overall size of the financial sector is important for the foreign direct investmenteconomic growth interaction. It is evident from these findings that there is no conclusive evidence on the impact of foreign direct investment on economic growth. Mosiori (2014) did research on the relationship between foreign direct investment and economic growth in Kenya between the years 1994-2014. The author used correlation analysis, from the findings; the study revealed that foreign direct investment positively influences the economic growth in Kenya. Therefore, the study recommended that the government policy makers need to push reform agenda in the domestic market so as to attract more foreign direct investment in the Kenyan economy since a higher investor's confidence in domestic market acts as a stimulus in attracting foreign direct investment inflows.

\section{Foreign Portfolio Investment and Economic growth}

A study was done by Ekinci (2011) find the relationship between portfolio investment and economic growth. The study was done on 30 Organization for Economic Cooperation and Development Countries another study between the 1996 and 2008. The researcher used panel data analysis also another study by Rachdi and Saidi (2011) to find the relationship between the two variables on 100 developing and developed nations between 1990 and 2009. The study used panel data analysis. The findings on the two research studies show that there is no relationship between portfolio investments and economic growth.

Tokunbo et al (2010) did a study on the impact of foreign portfolio to developing countries in sub-Sahara African countries including Nigeria. The study mentions that despite the flow of foreign portfolio low level of per capita income, high unemployment rate, low and falling gross domestic product are still prevalent in these countries. The Nigerian government had initiated policies to attract Foreign Portfolio Investment but this has not impacted positively on the growth rate of gross domestic product. The study therefore analyzed the direction and significance of the effect of Foreign Portfolio Investment in the economic growth in Nigeria covering the period 1990-2005. The study revealed that foreign portfolio investment, domestic investment growth and net export growth impacted positively and significance on economic growth in Nigeria.

According to research by Kula (2003), on the relationship between foreign portfolio investment and economic growth in Turkey between the periods 1980 to 2000 . The study used correlation analysis and the findings show that in Turkey there's a negative relationship between foreign portfolio investments and economic performance of the economy.

\section{Diaspora remittances and economic growth}

According to a study World Bank (2008) study on what impact remittances have on economic growth will depend on the policies being implemented by the home country. This study found out a number of areas that are complements to remittances in the matter of enhancing economic growth. This study included interaction terms with for remittances and education, remittances and financial depth, remittances and institutional qualities, and remittances and macroeconomic policy distortions. Pradhan et al. (2010) on the impact of workers' remittances on economic growth took samples from 39 developing economies, and used panel data for the periods 1980 to 2004 . The findings show that real per capita is the dependent variable while investment, openness, polity and remittances are the independent variables. They found that the proportion of worker's remittances that was used for investment enhanced economic growth. A $10 \%$ increase in the rate of investment led to $24.3 \%$ increases in per capita output.

On the study by Fayissa and Nsiah (2010) on the contribution of remittances on economic, used panel data 37 African countries for periods 1980-2004. The study used a cobDouglas production function to carry out the study. They investigated the contribution of remittances to economic growth relative to other factors that influence growth such as foreign direct investment, foreign aid, human and physical capital, openness of a country, polity and lagged income. They found that remittances influence on economic growth was positive and significant. A $10 \%$ increase in remittances led to $0.3 \%$ increase in gross domestic product per capita.

A recent study by Ahamada and Coulibaly (2013) examined causality between remittances and growth in Sub Saharan Africa. They used data for 20 countries that were in the sample used by Singh et. al. (2010) between 1980-2007 periods. Using granger causality test for panel data $i$, they found that remittances do not affect economic growth nor does economic growth affect remittances inflows. Extending the study to examine the link between remittances and physical output in the 20 countries, they found it was only in Gambia where remittances enhanced physical output and physical output enhanced remittances. According to research done by Bett (2011) on effects of diaspora remittances on economic growth in Kenya, the author used the multiple regression analysis and findings showed that the impact of diaspora remittances not only related to the economic growth, but they also influenced the economic growth in Kenya.

\section{METHODOLOGY}

\section{Research design}

This study adopted a descriptive research design. Descriptive research design has been seen by many studies as one that 
provides good description of the actual behaviour of a phenomenon (Mugenda \& Mugenda, 2012). It involved the collection and well-organized analysis of data to produce the correct representation of the behaviour of the variables. This method was chosen since it's precise, correct and involves description of events in a planned way (Babbie, 2007).

\section{Population and sample size}

Quarterly data on foreign direct investment, diaspora remittances and foreign portfolio investment flows to the Kenyan Economy were extracted from reliable sources that is, the Kenya National Bureau of Statistics and Central Bank of Kenya. In this study the period of $2002 q 1$ to $2017 q 4$ was chosen.

\section{Data Collection Technique}

The nature of this study made it necessary for secondary data to be used. The data obtained include foreign direct investment, foreign portfolio investment, diaspora remittances and gross domestic product in quarters from the year $2002 q 1$ to $2017 q 4$. By the nature of these variables, the nature of the data was time series and was used to determine the impact of capital flows on economic growth.

\section{Model Specification}

For the purpose of this study, the dependent variable was the Gross domestic product growth rate, and independent as net foreign direct investment, net foreign portfolio investment and diaspora remmitance. Therefore, the model, this study employed is specified as below

$$
\begin{aligned}
& G D P G R=f(F P I, F D I, R E M) \\
& \text { GDP }=\text { Gross Domestic Product } \\
& \text { Growth Rate } \\
& \text { FPI }=\text { Foreign Portfolio Investment } \\
& \text { FDI }=\text { Foreign Direct Investment } \\
& \text { REM }=\text { Diaspora Remmittances }
\end{aligned}
$$

\section{The Autoregressive Distributed Lag (ARDL) Model}

The study will assume a simple case of explanatory variables and a linear relationship as follows

$$
\begin{aligned}
\Delta \ln G D P G R_{t}= & \alpha_{0}+\sum_{i=1}^{p} \beta_{1 i} \Delta G D P G R_{t-1} \\
& +\sum_{i=0}^{q} \beta_{2 i} \Delta F D I_{t-i}+\sum_{i=0}^{q} \beta_{3 i} \Delta F P I_{t-i} \\
& +\sum_{i=0}^{q} \beta_{4 i} \Delta R_{t-i}+\delta_{2} G D P_{t-1}+\delta_{3} F D I_{t-1} \\
& +\delta_{4} F P I_{t-1}+\delta_{4} R_{t-1}+\varepsilon_{t}
\end{aligned}
$$

Where $\mu_{t}$ a stationary error term and the individual coefficients $\beta \mathrm{s}$ is represents the lag weights which collectively comprise the lag distribution and $y_{t}$ and $x_{t}$ have to be stationary variables. This model defines the pattern of how the different type of flows affect economic growth over time similar to an infinite moving average representation of an ARMA $(p q)$ process, except that the lagged polynomial on the right-hand side is applied to the explanatory variable $\mathrm{x}$ and not the white-noise process $\boldsymbol{\varepsilon}$.

\section{RESULTS AND DISCUSSION Descriptive statistics}

The summary statistics of the variable used in this study are presented in Table 4.1 below. The mean value of growth rate of GDP is 6.606 with FPI recording the highest mean value of Ksh Million 1100000 and DR having the lowest mean value of Ksh Million 22137.29. The average value of foreign direct investment was Ksh Million 861000. $-12.7 \%$ was the minimum GDP growth rate value recorded in the fourth quarter of 2012 while the highest recorded GDP growth rate was 40.8 in the third quarter of 2011.

The skewness and kurtosis values of all the variables used in the models evidenced that the variables were normally distributed. The Jarque-Bera normality test was conducted and the tests results showed that the variables were normally distributed. This was supported by the $\mathrm{p}$ values that showed their level of significance at $10 \%, 5 \%$ and $1 \%$ as shown in table 4.1 showing

Table I: Descriptive statistics

\begin{tabular}{lllllllll}
\hline Variable & Obs & Mean & Std. Dev. & Min & Max & Skew. & Kurt. & JB \\
\hline GDPGR & 64 & 6.606 & 8.425 & -12.7 & 40.8 & 1.2 & 6.082 & $4.681^{*}$ \\
FDI & 64 & 861000 & 445000 & 99519 & 1973405 & .562 & 2.537 & $6.123^{* *}$ \\
FPI & 64 & 1100000 & 1340000 & 193128 & $1.00 \mathrm{e}+07$ & 4.646 & 31.238 & $2378^{* * *}$ \\
DR & 64 & 22137.29 & 13587.38 & 6665.3 & 56450.4 & .63 & 2.121 & $6.296^{* *}$
\end{tabular}

$*, * *$, and $* * *$ shows the level of significance of $p<0.10, p<0.05$, and $p<0.01$ respectively

\section{Correlation Test Analysis}

Correlation matrix determined the static relationship between the variables in the growth regression. Table below shows the correlation between the Capital flows variables and the economic growth variable. The nexus between the natural $\log$ of GDP growth rate and the natural $\log$ of foreign direct investment had weak but significant positive nexus ( $\mathrm{r}=$ 0.398*). Natural $\log$ of FPI had a weak but positive association with the Natural log of GDP growth rate $(\mathrm{r}=$ $0.371^{*}$ ). Natural $\log$ of DR also had a weak and positive association with Natural $\log$ of GDP growth rate $\left(\mathrm{R}=0.434^{*}\right)$. 
Overally, from the correlation matrix, the independent variables have high association amongst themselves.

Table II: Correlation Matrix Analysis

\begin{tabular}{cllcc}
\hline Variables & LNGDPG $\%$ & LNFDI & LNFPI & LNDR \\
\hline LNGDPGR & 1.000 & & & \\
\hline LNFDI & $0.398^{*}$ & 1.000 & & \\
& 0.000 & & 1.000 & \\
\hline LNFPI & $0.371^{*}$ & $0.493^{*}$ & & 1.000 \\
& 0.000 & 0.000 & $0.512^{*}$ & \\
\hline LNDR & $0.434^{*}$ & $0.917^{*}$ & 0.000 & \\
& 0.000 & 0.000 & & \\
\hline
\end{tabular}

* Shows significance at the .01 level

\section{Autoregressive Distributed Lag Model (ARDLM)}

The results only present the short run relationship between capital flows variables and economic growth. Foreign direct investment and its lag had a positive but insignificant effect on the gross domestic product growth rate while foreign portfolio investment and its first and third lag had a positive and statistically significant short run effect on gross domestic product growth at the $1 \%$ and $5 \%$ levels of significance respectively. Diaspora Remittances had a positive and significant effect on the gross domestic product growth rate at $5 \%$ level of significance. The adjusted R-squared of the Auto-regressive Distribution Lag model is higher compared to the adjusted R-squared of the Error correction model. This means that Auto-regressive Distribution Lag model had many errors within the model that made model looks best fitting while in real sense it was giving spurious high values.

Table: ARDL Regression Results

\begin{tabular}{|c|c|c|c|c|c|c|}
\hline LNGDPGR & & Coef. & Std. Err. & $\mathbf{P}>\mathbf{t}$ & [95\% Conf. & Interval] \\
\hline L(LNGDPGR(-1)) & & -0.054 & 0.162 & 0.745 & -0.394 & 0.286 \\
\hline LNFDI & & 2.045 & 1.202 & 0.105 & -0.472 & 4.561 \\
\hline L(LNFDI(-1)) & & 2.142 & 1.276 & 0.109 & -0.528 & 4.812 \\
\hline LNFPI & & $0.550 * *$ & 0.195 & 0.011 & 0.142 & 0.958 \\
\hline L(LNFPI(-1)) & & $0.607 * * *$ & 0.177 & 0.003 & 0.237 & 0.977 \\
\hline L(LNFPI(-2)) & & 0.236 & 0.180 & 0.205 & -0.141 & 0.614 \\
\hline L(LNFPI(-3)) & & $0.687 * * *$ & 0.166 & 0.001 & 0.341 & 1.034 \\
\hline LNDR & & $3.474 * *$ & 1.276 & 0.014 & 0.803 & 6.144 \\
\hline TIME(QUARTERLY) & & $-0.289 * * *$ & 0.073 & 0.001 & -0.443 & -0.136 \\
\hline CONSTANT & & $-107.622 * * *$ & 26.084 & 0.001 & -162.064 & -53.179 \\
\hline R-squared & $=$ & 0.8973 & \multicolumn{2}{|c|}{ Adj R-squared } & & $=0.8486$ \\
\hline Log likelihood & $=$ & -7.3832263 & \multicolumn{2}{|c|}{ Prob $>$ F } & & 0.0000 \\
\hline AIC & $=$ & 34.76645 & \multirow{2}{*}{\multicolumn{2}{|c|}{ Root MSE }} & & $=0.3856$ \\
\hline BIC & $=$ & 48.43941 & & & & \\
\hline
\end{tabular}

\section{Error Corrected ARDL Model}

The error correction model estimates the short run and long run effects of time series on each other. The table below shows the error correction model results of Auto-regressive Distribution lag model. It displays the short run and long run effects of the capital flows variables on economic growth variable, including their lags on their first differences.
The error corrected Auto-regressive Distribution Lag model below describes the dynamic effects of changes of the explanatory variables upon current and future values of the gross domestic product. Coefficient of determination also known as the Adjusted R-squared was estimated at 0.64 implying that $64 \%$ of the total variation in the gross domestic product growth rate is explained by the total variation in capital flows variables in the model (both present and past). 
Table III: Error Correction Model for Auto-Regressive Distribution Lag Model.

\begin{tabular}{|c|c|c|c|c|c|c|}
\hline LNGDPGR & & Coef. & Std. Err. & $P>t$ & [95\% Conf. & Interval] \\
\hline & L(LNGDPGR(-1)) & $-1.054 * * *$ & 0.162 & 0.000 & -0.714 & -0.714 \\
\hline \multicolumn{7}{|l|}{ LR } \\
\hline & LNFDI & $3.973 * * *$ & 1.363 & 0.009 & 1.119 & 6.827 \\
\hline & LNFPI & $1.975 * * *$ & 0.259 & 0.000 & 1.432 & 2.517 \\
\hline & LNDR & $3.296 * * *$ & 1.124 & 0.009 & 0.944 & 5.649 \\
\hline \multicolumn{7}{|l|}{ SR } \\
\hline & D(LNFDI) & 2.045 & 1.202 & 0.105 & -0.472 & 4.561 \\
\hline & D(LNFPI) & $0.550^{* *}$ & 0.195 & 0.011 & 0.142 & 0.958 \\
\hline & L1D(LNFPI) & $-0.924 * * *$ & 0.247 & 0.001 & -1.440 & -0.407 \\
\hline & L2D(LNFPI) & $-0.687 * * *$ & 0.166 & 0.001 & -1.034 & -0.341 \\
\hline & D(LNDR) & $3.474 * *$ & 1.276 & 0.014 & 0.803 & 6.144 \\
\hline & TIME(QUARTERLY) & $-0.289 * * *$ & 0.073 & 0.001 & -0.443 & -0.136 \\
\hline & CONSTANT & $-107.911 * * *$ & 26.084 & 0.001 & -162.505 & -53.317 \\
\hline R-squared & $=$ & 0.7566 & & \multicolumn{2}{|c|}{ Adj R-squared } & $=0.6413$ \\
\hline Log likelihood & $=$ & -7.3832263 & & \multicolumn{2}{|c|}{ Prob $>$ F } & $=0.0000$ \\
\hline AIC & $=$ & 34.76645 & & \multicolumn{2}{|c|}{ Root MSE } & $=0.3856$ \\
\hline BIC & $=$ & 48.43941 & & & & \\
\hline
\end{tabular}

Note; **, *** implies level of significance at $5 \%$ and $1 \%$ respectively

Short-run effect of foreign direct investment, foreign portfolio investment and diaspora remittances on Economic Growth in Kenya

Notably, natural $\log$ of foreign direct investment had a positive but insignificant effect on the natural log of GDP growth rate. This means that a $1 \%$ increase in foreign direct investment inflows leads to an insignificant immediate and short run effect on the economic growth. However, the trending variable, TIME (QUARTERLY) had a negative and very significant short run effect on the natural GDP growth rate at $1 \%$ level of significance. Such that the exogenous time factor in the capital flows short run and long run effect on the economic growth is negative.

The first difference of natural $\log$ of foreign portfolio investment had a positive and significant short run effect on the natural log of GDP growth rate. This implies that an increase in differencing level of natural log of FPI causes an immediate $55.0 \%$ increase in GDP growth rate. Significantly, the study results are consistent with the findings of the International Capital Flows and economic growth study by IMF (2011), Prasad et al. (2006) who emphasized the positive correlation between economic growth and capital flows in developing countries, and concluded that international capital flows may even hurt economic growth in developing countries. The first and second lagged first difference of natural log of FPI had a negative and very significant short run effect on the natural GDP growth rate at $1 \%$ level of significance. The study findings contradict the results of the study by Ocharo et al. (2014) which established that there is a unidirectional causality from FPI to economic growth. Moreover, the first difference natural $\log$ of DR had a very positive and significant short run effect on the natural GDP growth rate. This means that a $1 \%$ increase in diaspora remittances leads to 3.474 times increase in economic growth.

Long-run effect of Foreign Direct Investment, Foreign portfolio investment and Diaspora remittances on Economic Growth in Kenya

The natural $\log$ of foreign direct investment had a positive and very significant (1\% level) long run effect on natural log of GDP growth rate. This means that as foreign direct investment changes with time, the economic growth's speed of adjustment will be 3.973 times in Kenya for it to reach the long run equilibrium. This is consistent with previous findings of the study by Ocharo et al. (2014), Ngeny and Mutuku (2014) that found that foreign direct investment has a positive influence on economic growth in Kenya. Therefore, foreign direct investment causes economic growth. The natural log of FPI has a very significant and positive long run effect on the natural log of GDP growth. The relationship is significant at $1 \%$ level. This means that, to realize the long run equilibrium, as foreign portfolio investment changes, economic growth in Kenya will have to adjust by 1.75 times.

The study findings on the effect of Foreign Portfolio Investment on economic growth are in agreement with the findings of the IMF (2011) study. Thus, foreign direct investment positively impacts on economic growth and hence should be encouraged and proper and necessary policy support for efficient flow of capital into the economy. The findings of this study agree with findings form the study carried out by Tokunbo (2010) that foreign portfolio 
investment among domestic investment positively and significantly impacts on economic growth of most of the developing economies. The natural $\log$ of diaspora remittances has a positive long run effect on the natural log of gross domestic product growth. The relationship is significant at $1 \%$ level. It implies that as diaspora remittances changes, and then economic growth has to adjust 3.296 times to attain the long run equilibrium. Therefore, diaspora remittances cause a positive impact on economic growth.

\section{CONCLUSION}

The objective of this study was to investigate the effects of foreign capital flows on economic growth in Kenya using the gross domestic product growth rate as the indicator for

\section{REFERENCES}

1. Adeniyi, O., Omisakin, O., Egwaikhide, F.O. \& Oyinlola, A. (2012).Foreign direct investment, economic growth and financial sector development in small open developingeconomies.Economic Analysis and Policy, 42(1), 105-128.

2. Aizenman, J., Jinjarak, Y., Park, D. (2011). Capital flows and economic growth in the era of financial integration and crisis, 1990-2010. National Bureau of Economic Research, 24(3), 371-396. doi: 10.1007/s11079-012-9247-3.

3. Ahamada, I. and Coulibaly, D. (2013). Remittances and growth is Sub Saharan African Countries. Journal of International Development, 25(1), 310324.

4. Babbie, E. (2007). The basics of social research. Belmont, CA: Wadsworth/Thomson Learning.

5. Blair, H. (2003). Capital-Account Liberalization, the cost of capital and economic growth.

American Economic Review, 93(2), 91-96.

6. Bett, L. (2011). Effect of remittances on economic growth of Kenya.

7. Chowdhury, A. \& Marrotas, G. (2005).Foreign direct investment and growth: A causal relationship. World Institute for Development Economics Research, Research Paper No. 2005/25.

8. Edwards, S. (2004).Financial openness, sudden stops and the current account reversal. American Economic Review, 94, 59-64.

9. Evans, M. D., \& Hnatkovska, V. (2007). Financial Integration, Macroeconomic Volatility and Welfare. Journal of the European Economic Association, 5(2-3), 500-508.

10. Fayissa B. and Nsiah C. (2010). The impact of remittances on economic growth and Development in Africa. The American Economist, 55(2), 92-103

11. Kula, F. (2003). Effectiveness of international capital movements: Observations on Turkey. economic growth. The study analysed the effects of foreign direct investment flows, foreign portfolio investment and Diaspora remittances on the economic growth in Kenya over 64 quarterly periods from $2002 q 1$ to $2017 q 4$. The secondary data was sourced from the Kenya Bureau of Statistic annual economic surveys as well as economic growth data published by the Central Bank of Kenya.

From the analysis, it is concluded that foreign capital flows had a positive effect on economic growth. These three capital flows also have a significant impact on economic growth. Therefore, to stimulate the economy, Kenya can put more focus on creating a good and conducive environment for foreign direct investment, foreign portfolio investment and diaspora remittances to flow into the economy.

Journal of Faculty of Economics and Administrative Sciences, 4 (2), 141-154.

12. Levine, R., \& Zervos, S. (1996). Stock market development and long-run growth. The World Bank Economic Review, 10(2), 323-339

13. Levine, R. and Carkovic, M. (2002) .Does foreign direct investments accelerate economic growth? SSRN Electric Journal.doi: 10.2139/ssrn.314924.

14. Mosiuri M. (2012). The relationship between foreign direct investment and economic growth in Kenya.

15. Mugenda O. N \& Mugenda A.G. (2012).Research methods dictionary. Nairobi: Applied research and training services.

16. Pradhan,G., Upadhyay, M. \& Upadhyay, K. (2010). Remittances and economic growth in developing countries. European Journal of Development Research, 20(3), 497- 506.

17. Singh, R.J., Haacker, M., Lee, K. and Goff, M.L. (2010).Determinant and macroeconomic impact of remittances in Sub-Saharan Africa. Journal of African Economies, 20(2), 312- 340

18. Tokunbo S., Lloyd A. (2010).Foreign private investment and economic growth in Nigeria. Review of Economic and Business Studies.3 (1), 105-127. 